\title{
TRANSFORMASI CERITA ENDANG RARA TOMPE DALAM PERTUNJUKAN KETHEK OGLENG PACITAN
}

\section{TRANSFORMATION OF ENDANG RARA TOMPE STORY IN PACITAN KETHEK OGLENG PERFORMANCE ART}

\author{
Arif Mustofa, Agoes Hendriyanto, Bakti Sutopo \\ Pendidikan Bahasa dan Sastra Indonesia STKIP PGRI Pacitan \\ Jalan Cut Nya' Dien No. 4a Pacitan Jawa Timur Kode Pos 63515, Indonesia \\ mustofarif99@yahoo.com; rafidmusyffa@gmail.com; bakti080980@yahoo.co.id
}
(Naskah diterima tanggal 26 April 2019, direvisi terakhir tanggal 16 April 2020, dan disetujui tanggal 28 April 2021)
DOI: https:/ / doi.org/10.26499/wdprw.v49i1.294

\begin{abstract}
This research aims to: 1) describe the plot of Endang Roro Tompe story and Kethek Ogleng performance art; 2) describe the transformation process of Endang Roro Tompe story into Kethek Ogleng performance art. The data were collected by these four steps: 1) observing Kethek Ogleng performance art, 2) recording the video and audio of Endang Rara Tompe's story ; 3) describing the video recording based on the performance and transcribing the audio recording of Endang Roro Tompe. The result shows that Kethek Ogleng performance art is influenced by the plot of Panji Endang Rara Tompe. However, in the whole story, the performance only takes several scenes: The monkey comes, the monkey meets Endang Rara Tompe, the monkey falls in love with Endang Rara Tompe, and the monkey leaves back to the kingdom. There are two changing patterns from Endang Rara Tompe's hypogram into Kethek Ogleng performance art. The first change deals with the cut of scenes. Kethek Ogleng performance art only explains the end of Endang Rara Tompe's story. The story of Jenggala Kingdom is omitted in Kethek Ogleng performance art. The second is changing the main character. The author changes the main character from Dewi Sekartaji into Panji Asmarabangun or the monkey.
\end{abstract}

Keywords: transformation; story; performance art; Kethek Ogleng

\begin{abstract}
Abstrak
Penelitian ini bertujuan untuk: 1) menghasilkan deskripsi pola alur Cerita Endang Rara Tompe dan pertunjukan Kethek Ogleng; 2)menghasilkan deskripsi proses transformasi dari Cerita Endang Rara Tompe ke pertunjukan Kethek Ogleng. Data dikumpulkan dengan cara: 1) pengamatan pertunjukan Kethek Ogleng; 2) perekaman video pertunjukan Kethek Ogleng dan perekaman audio cerita Endang Rara Tompe; 3) pendeskripsian struktur pertunjukan pertunjukan; pentranskripsian hasil rekaman cerita Endang Rara Tompe. Analisi data dilakukan dengan cara 1) menyusun struktur pertunjukan (visual) Kethek Ogleng; 2) menyusun struktur cerita (lisan) Endang Rara Tompe; 3) membandingkan struktur pertunjukan (visual) Kethek Ogleng dengan struktur cerita (lisan) Endang Rara Tompe; 4) menganalisis pola perbedaan dan persamaan antara bentuk lisan dan bentuk visual. Hasil analisis menunjukkan bahwa struktur pertunjukan Kethek Ogleng dipengaruhi oleh pola alur cerita Panji Endang Rara Tompe. Namun, secara keseluruhan kisah, hanya diambil beberapa pertistiwa saja yaitu: kemunculan kera, pertemuan kera dengan Endang Rara Tompe, adegan jatuh cinta, dan adegan kembali ke kerajaan. Terdapat dua pola pemindahan dari hipogram Cerita Endang Rara Tompe ke pertunjukan Kethek Ogleng. Pertama yaitu pemotongan Adegan. Pertunjukan Kethek Ogleng hanya berisi bagian akhir dari
\end{abstract}


cerita Endang Rara Tompe. Adegan kerajaan Jenggala tidak dimunculkan dalam pertujukan Kethek Ogleng. Keduaya itu alih tokoh utama. Pengarang mengubah tokoh utama dari Dewi Sekartaji menjadi Panji Asmarabangun atau tokoh kera.

Kata-kata Kunci: transformasi; cerita; pertunjukan; Kethek Ogleng

\section{Pendahuluan}

Asumsi bahwa karya satu dengan karya lain saling memengaruhi sudah lama dibicarakan dalam kajian intertekstual. Karya yang baru bisa jadi merupakan peresapan atau reaksi dari karya yang sudah ada. Andayani, (2011) menyatakan bahwa riset intertekstual sebenar-nya merupakan usaha memahami bahwa suatu teks baru mengandung teks sebelumnya. Fokus penelitian intertekstual adalah teks terdahulu (prior text) sebagai penyumbang kode yang memungkinkan lahirnya berbagai efek signifikansi.

Gejala saling memengaruhi antara karya satu dengan yang lainnya tidak selalu tanpa kesadaran. Ada beberapa seniman dengan sengaja mengubah karya yang sudah ada ke dalam bentuk yang lain. (Ratna, 2010: 215) menyatakan bahwa proses peniruan tidak harus plagiat. Peniruan dalam proses kreatif berarti memberikan muatan, arti, dan makna yang baru.

Wacana saling meniru, seperti yang disampaikan dalam kajian intertekstual, tentunya tidak hanya terjadi antar teks sastra. Namun, saling mempengaruhi bisa terjadi lintas karya seni. Misalnya dari dari puisi menjadi lagu.

Terdapat empat cara pemindahan dari hipogram, yaitu: a) ekspansi, b) konversi, c) modifikasi, dan d) ekserp (Azizah dkk., 2018) Ekspansi yaitu Pemutarbalikan hipogram. Mengubah kalimat dengan sejumlah faktor yang sama. Konversi berarti pemutarbalikan hipogram atau matriksnya dengan mengubah unsur-unsur kalimat matrik dengan sejumlah faktor yang sama dengan bentuk yang berbeda. Modifikasi berarti perubahan pada tataran linguistik, manipulasi urutan kata dan kalimat; pada tataran kesastraan, yaitu manipulasi tokoh atau alur. Ekserp yaitu intisari dari hipogram disadap pengarang (Riffaterre, 1978)

Proses transformasi karya sastra, bisa saja karya tersebut mengikuti dengan setia atau bisa menyimpanginya (Haryatmo, 2015). Hal inilah yang membuat satu karya bisa melahirkan beberapa bentuk karya hasil transformasi yang berbeda. Seperti kisah Panji yang ditransformasi ke dalam berbagai karya seni. Manuaba (2013) menyatakan bahwa cerita Panji telah ditransformasi ke dalam beberapa karya seni yaitu (1) seni sastra, (2) seni relief, (3) seni pertunjukan, dan (4) seni lukis.

Kisah Panji yang ditransformasi ke dalam seni pertunjukan juga terjadi di Pacitan. Meskipun Pacitan secara kulturan lebih dekat ke wilayah Yogyakarta, namun kisah Panji juga berkembang di Pacitan. Selain pertunjukan Wayang Beber yang berisi cerita Panji, juga terdapat pertunjukan Kethgek Ogleng yang sangat dipengaruhi oleh cerita Panji Endang Rara Tompe.

Pertunjukan Kethek Ogleng yang berkembang di Desa Tokawi Kecamatan Nawangan Kabupaten Pacitan diciptakan oleh Sutiman pada tahun 1962. Pada awalnya, pertunjukan ini murni meniru gerakan kera. Namun, dalam perkembangannya, pertunjukan ini merujuk pada kisah Panji yang berjudul Endang Rara Tompe. Suksino (wawancara 8 Maret 2018) mengatakan bahwa ide awal pertunjukan Kethek Ogleng yaitu meniru perilaku gerak kera. Namun, pertunjukan menggambarkan cerita Endang Rara Tompe. 
Penelitian dengan objek kisah Panji di Jawa Timur telah banyak dilakukan. Misalnya Analisis Struktur Cerita Panji dalam Pertunjukan Drama Tari Wayang Topeng Malang Lakon Panji Reni oleh Hikmah \& Roihanah (2017) Penelitian ini sebatas menunjukkan struktur cerita Panji yang terdapat dalam drama tari wayang Topeng Malang.

Penelitian transformasi dari sastra lisan ke dalam bentuk teks yang lain telah banyak dilakukan. Misalnya (Santosa \& Djamari, 2013) membandingkan tiga puisi modern Indonesia yang berisi kisah Nabi Luth bersama Kaum Sodom dan Gomora, yaitu puisi "Sodom dan Gomora" Subagio Sastrowardojo, "Balada Nabi Luth AS" Taufiq Ismail, dan "Apakah Kristus Pernah?" Darmanto Jatman. Hasil analisis menunjukkan bahwa ketiga puisi modern Indonesia tersebut merupakan mosaik, kutipan-kutipan, penyerapan dan transformasi teks-teks kisah Nabi Luth bersama Kaum Sodom dan Gomora yang terdapat dalam Alkitab, AlQuran, Cerita-cerita Alkitab Perjanjian Lama, dan Qishashul Anbiya.

Di pihak lain, Sidik (2016) meneliti Tranformasi Kisah Ashabul Kahfi dalam Ahlul Kahfi Karya Taufiq Al-Hakim. Penelitian ini menghasilkan temuan bahwa bahwa naskah drama Ahlul Kahfi merupakan penyerapan, dari kisah Ashabul Kahfi seperti yang terdapat dalam Alquran. Penelitian ini menyimpulkan bahwa drama Ahlul Kahfi diciptakan karena adanya kisah Ashabul Kahfi.

Sementara itu, Ramadhanti \& Yanda (2018) mengkaji Transformasi teks Kaba Sabai nan Aluih menjadi Komik Kaba Sabai nan Aluih. Hasil penelitian ini menunjukkan terdapat reduksi tokoh cerita, penambahan latar cerita, dan perubahan di akhir cerita yang terdapat dalam Komik Kaba Sabai nan Aluih.

Berbeda dengan peneitian-penelitian di atas, yang hanya membuktikan adanya hu- bungan intertekstual. Penelitian ini mencoba menganalisis pola perubahan cerita rakyat yang berbentuk lisan ke pertunjukan yang berbentuk visual. Pola transformasi ini akan tentunya akan melengkapi penelitian (Manuaba, 2013) yang secara umum telah menunjukkan bentuk-bentuk karya seni hasil transformasi kisah Panji.

Berdasar latar belakang di atas, rumusan masalah dalam penelitian ini yaitu bagaimana bentuk transformasi kisah Endang rara Tompe dalam pertunjukan Kethek Ogleng.

Hasil penelitian diharapkan menghasilkan: 1) deskripsi struktur naratif Cerita Endang Rara Tompe yang ditransformasi dalam pertunjukan Kethek Ogleng; 2). deskripsi proses transformasi dari Cerita Endang Rara Tompe ke pertunjukan Kethek Ogleng.

\section{Metode}

Penelitian ini dilaksanakan di Desa Tokawi Kecamatan Nawangan Kabupaten Pacitan. Secara geografis, terletak $40 \mathrm{~km}$ sebelah utara kota Pacitan.

Penelitian ini mengkaji tindakan dan perilaku suatu komunal. Sehingga, digunakan pendekatan antropologis. Ratna (2020) mendefinisikan pokok-pokok bahasan yang ditawarkan dalam pendekatan antropologi yaitu: (1) aspek-aspek naratif karya sastra dari kebudayaan yang berbeda-beda; (2) penelitian aspek naratif sejak epik paling awal hingga novel yang paling modern; (3) bentuk-bentuk arkhais dalam karya sastra, baik dalam konteks karya individual maupun narasi; (4) bentuk-bentuk mitos dan sistem religi dalam karya sastra; (5) pengaruh mitos, sistem religi, dan citra primordial yang lain dalam kebudayaan populer.

Data dianalisis secara deskriptif analitik. Artinya, data dideskripsikan dengan cara menggambarkan kondisi yang ditemukan dilanjutkan dengan analisis. Metode deskriptif analitik melakukan pembahasan dengan cara 
mendeskripsikan fakta-fakta kemudian disusul dengan analisis (Hasanah dkk., 2018)

Sumber data dalam penelitian ini yaitu pertunjukan Kethek Ogleng dan cerita Endang Rara Tompe. Sedangkan data dalam penelitian ini yaitu deskripsi gerak pertunjukan kethek Ogleng dan kalimat dalam cerita Endang Rara Tompe.

Pertunjukan Kethek Ogleng yang menjadi bahan kajian ini dimainkan oleh siswa Sanggar Condro Wanoro. Sanggar ini secara konsisten melestarikan pertunjukan Kethek Ogleng.

Narasumber utama untuk menggali cerita Endang Rara Tompe yaitu Sutiman pencipta Kethek Ogleng dan Sukisno pemilik sanggar Condro Wanoro.

Pengumpulan data, dilakukan dengan langkah berikut:

1. Observasi pertunjukan Kethek Ogleng. Observasi mengungkapkan gambaran sistematis mengenai peristiwa, tingkah laku, benda atau karya yang dihasilkan dan peralatan yang digunakan (Rohidi, 2011). Observasi dilakukan untuk melihat secara langsung gerak, interaksi antar pemain, dan reaksi penonton tari kethek Ogleng.

2. Mengadakan perekaman Video pertunjukan Kethek Ogleng dan perekaman audio Cerita Endang Rara Tompe. Perekaman video dan audio untuk memperkuat data observasi.

3. Hasil video pertunjukan kemudian dideskripsikan sesuai langkah-langkah pertunjukan; sedangkan rekaman berupa suara penutur cerita Endang Rara Tompe ditranskrip menjadi bentuk tulis.

4. Hasil transkrip rekaman kemudian diterjemahkan ke dalam bahasa Indonesia untuk mempermudah pemaknaan.

Analisis data dilakukan dengan cara membandingkan struktur pertunjukan (visual) Kethek Ogleng sebagai hasil transformasi dari cerita (lisan) Endang Rara Tompe sebagai Hipogramnya.

\section{Hasil dan Pembahasan \\ 3.1Kisah Panji dalam Cerita Endang Rara Tompe}

Kisah Panji sangat populer di tanah Jawa. Selain mengisahkan petualangan, Panji juga mengisahkan percintaan keluarga raja. Pada zaman Majapahit, gelar Panji ada hubungannya dengan kerabat raja. Tokoh-tokoh utama dalam cerita roman ketika itu juga memakai gelar Panji. Dalam perkembangannya, gelar ini bertukar menjadi nama (Pigeaud, 1967). Perubahan dari gelar ke nama misalnya terjadi pada putra Ken Arok dengan Ken Umang yang diberi nama Panji Tohjoyo. Dengan demikian, Panji dalam perkembangannya bukan lagi gelar kebangsawanan, tetapi menjadi nama orang.

Pada umumnya, cerita Panji menampilkan alur khas yang sama, karena itu ada anggapan bahwa cerita Panji isi ceritanya sama. Namun, bila keseluruhannya dianggap sama, bisa jadi hal itu kurang tepat. Kisah Panji yang saat ini dijumpai, meskipun alurnya sama, namun terdapat motif-motif lain yang berbeda. Misalnya, cerita Panji biasanya terdapat empat buah kerajaan, yaitu Kuripan, Daha, Gagelang, dan Singasari. Namun, dalam beberapa cerita hanya dijumpai dua, atau tinga kerajaan saja. Bahkan, dalam cerita Ande-ande Lumut tidak menunjukkan adanya nama kerajaan. Namun, dalam dongeng tersebut alur dan nama tokoh menunjukkan adanya persamaan dengan kisah panji, yaitu adanya pengembaraan dan pencarian cinta.

(Poerbatjaraka, 1968) menyatakan bahwa secara umum, Kisah Panji berisi kisah percintaan yang di dalamnya terdapat peristiwa: pembunuhan kekasih, perjalanan atau pengembaraan, menghilang, dan penyamaran.

Berdasar ciri Kisah Panji seperti disampaikan Poerbatjaraka di atas, cerita Endang 
Rara Tompe setidaknya memiliki persamaan yaitu 1) berisi percintaan, 2) terdapat peristiwa menghilang, 3) kisah pengembaraan, dan 4) terjadinya penyamaran.

1) Motif Percintaan

Kisah percintaan merupakan motif utama kisah Panji. Sehingga hampir semua kisah Panji selalu tentang percintaan.

Cerita Endang Rara Tompe mengisahkan percintaan antara Dewi Sekartaji dan Panji Asmarabangun. Konflik cerita berawal dari kepergian Dewi Sekartaji dari Istana kerajaan karena cintanya kepada Panji Asmarabangun dilarang oleh sang ayah.

Tokoh dalam cerita Endang Rara Tompe berasal dari kerajaan Jenggala. Panji Asmarabangun adalah putra mahkota Jenggala sedangkan Dewi Sekartaji merupakan putri dari salah satu selir raja.

2) Motif Menghilang

Motif menghilang didapati pada hampir tiap cerita Panji. Hal inipun juga terjadi pada cerita Endang Rara Tompe. Dalam kisah ini, diceritakan Dewi Saekartaji menghilang dengan cara melarikan diri dari kerajan. Tidak diketahui secara pasti penyebab kepergiannya. Namun, terdapat pencerita yang mengatakan bahwa Dewi Sekartaji meninggalkajn kerajaan karena cintanya pada Asmarabangun ditentang ayahnya.

Berdasar penuturan Sukisno dan Sutiman (Maret 2018), Dewi Sekartaji menghilang dari istana sehingga membuat geger kerajaan.

Dalam cerita Endang Rara Tompe, motif menghilangnya Dewi Sekartaji merupakan pembangun cerita. Karena peristiwa ini (menghilang) maka cerita menjadi terbangun.

3) Motif Pengembaraan dan Penyamaran

Cerita Endang Rara Tompe menceritakan perjalanan Panji Asmarabangun mencari Dewi Sekartaji yang pergi meninggalkan istana.

Dalam perjalanannya, sesampai di Desa Tokawi, Dewi Sekartaji menyamar dan mengganti nama menjadi Endang Rara
Tompe. Sementara itu, Panji Asmarabangun atas petunjuk seorang Pendeta, menyamar menjadi seekor kera.

\subsection{Kethek Ogleng Pacitan}

Pertunjukan Kethek Ogleng di Desa Tokawi Kecamatan Nawangan Kabupaten Pacitan, setidaknya diperankan oleh dua penari yaitu penari Kethek (kera) dan penari perempuan yang memerankan Endang Rara Tompe. Namun, jumlah penari Kethek (Kera) dan penari pendamping Endang Rara Tompe dapat bertambah sesuai keinginan penanggap.

Selain itu, sebagi pendukung terdapat sepuluh pengrawit dan sinden. Namun demikian, saat ini keberadaan pengrawit sebagai pengiring musik sering digantikan oleh rekaman audio.

Sebagai salah satu bentuk kesenian, Kethek Ogleng merupakan salah satu kesenian yang di dalamnya banyak memiliki unsur-unsur seni seperti; gerak, rias, busana, iringan, tempat pementasan (Suseno, 2013).

Pertunjukan Kethek Ogleng di Kecamatan Nawangan bukan hanya sebagai sarana hiburan bagi masyarakat, tetapi juga sebagai tuntunan. Sukisno (wawancara 3 Maret 2018) menyatakan bahwa Kethek Ogleng juga merupakan sumber kaweruh (pengetahuan) masyarakat dalam menyikapi hidup; tatacara berinteraksi dengan sesama manusia maupun dengan alam.

Secara sepintas pertunjukan Kethek Ogleng hanya tiruan gerakan kera. Apabila dicermati, setiap gerakan mempunyai maksud dan makna sebagaimana karya seni yang lain. Gerakan-gerakan tersebut sebenarnya erat kaitannya dengan perilaku manusia dalam menjalani kehidupannya. Pada konteks ini, seni Kethek Ogleng dapat dikatakan sebagai medium penafsiran sekaligus pemahaman terhadap berbagai problema kehidupan. Tentu, tafsiran dan pemahaman yang tervisualiasi dalam gerakan seni Kethek 
Ogleng didasari oleh pandangan hidup masyarakat setempat, yakni masyarakat Jawa

\subsection{Pola Alur Cerita}

Alur atau Plot merupakan rangkaian peristiwa yang bersifat logis dan kronologis yang membentuk konflik-konflik berdasarkan hubungan sebab-akibat. Plot dengan demikian merupakan urutan peristiwa yang menjadi jalan peristiwa.

Nurgiyantoro (2005) menyatakan bahwa tahapan alur yaitu: 1) tahap awal, biasa dikenal dengan tahap pengenalan; 2) tahap tengah, atau biasa disebut tahap pertikaian; 3) tahap akhir atau biasa dikenal dengan sebutan sebagai tahap penyelesaian, menampilkan adegan tertentu sebagai akibat klimaks.

Cerita Endang Rara Tompe yang berkembang di desa Tokawi Nawangan beralur linier. Cerita disampaikan secara runtut dari pengenalan, konfilk dan penyelesaian konflik dengan runtut.

Alur linier lazim ditemukan di semua certa rakyat. Alur ini memudahkan pencerita menyempaikan isi cerita. Selain itu, alur linier membuat pendengar lebih mudah memahami cerita.

Begitupula dengan pertunjukan Kethek Ogleng. Struktur pertunjukan kethek Ogleng dimulai dengan adegan kemunculan kera, gerak blendrongan, kudangan, dan adegan kembali ke kerajaan.
Adegan kemunculan kera dilakukan dengan gerak improvisasi. Pemeran kera keluar ke panggung dengan gerakan meniru gerakan kera yang lincah dan menunjukkan keriangan. Gerakan pada tahap ini berupa melompat, merangkak, berguling, berjalan membungkuk, atau bergelantungan di tali. Sehingga suasana yang muncul yaitu kegembiraan.

Gerak Blendrongan menunjukkan pemeran kera bermain-main dengan penonton. Pemeran kera pada beberapa pertunjukan tampak inten berinteraksi dengan penonton. Misalnya mengambil barang milik penonton, meminta gendong penonton, dan menggandeng tangan penonton.

Gerak Kudangan dimainkan dengan pakem. Pemeran kera menari dengan pemeran Endang Rara Tompe dengan gerakan halus. Penuh simbolisasi rasa kasmaran. Adegan ini memang menunjukkan peristiwa Kera dan Endang Rara Tompe saling jatuh cinta.

Gerakan terakhir yaitu kembalinya Kera dan Endang Rara Tompe ke balik panggung atau pulang. Adegan ini, kera menggandeng Endang Rara Tompe. Suasana yang dimunculkan yaitu kegembiraan dan kebahagiaan.

Berikut ini pola alur pertunjukan Kethek Ogleng dan pola alur cerita Endang Rara Tompe. 


\section{Bagan 1}

Alur dan latar suasana pertunjukan Kethek Ogleng dan Cerita Endang Rara Tompe

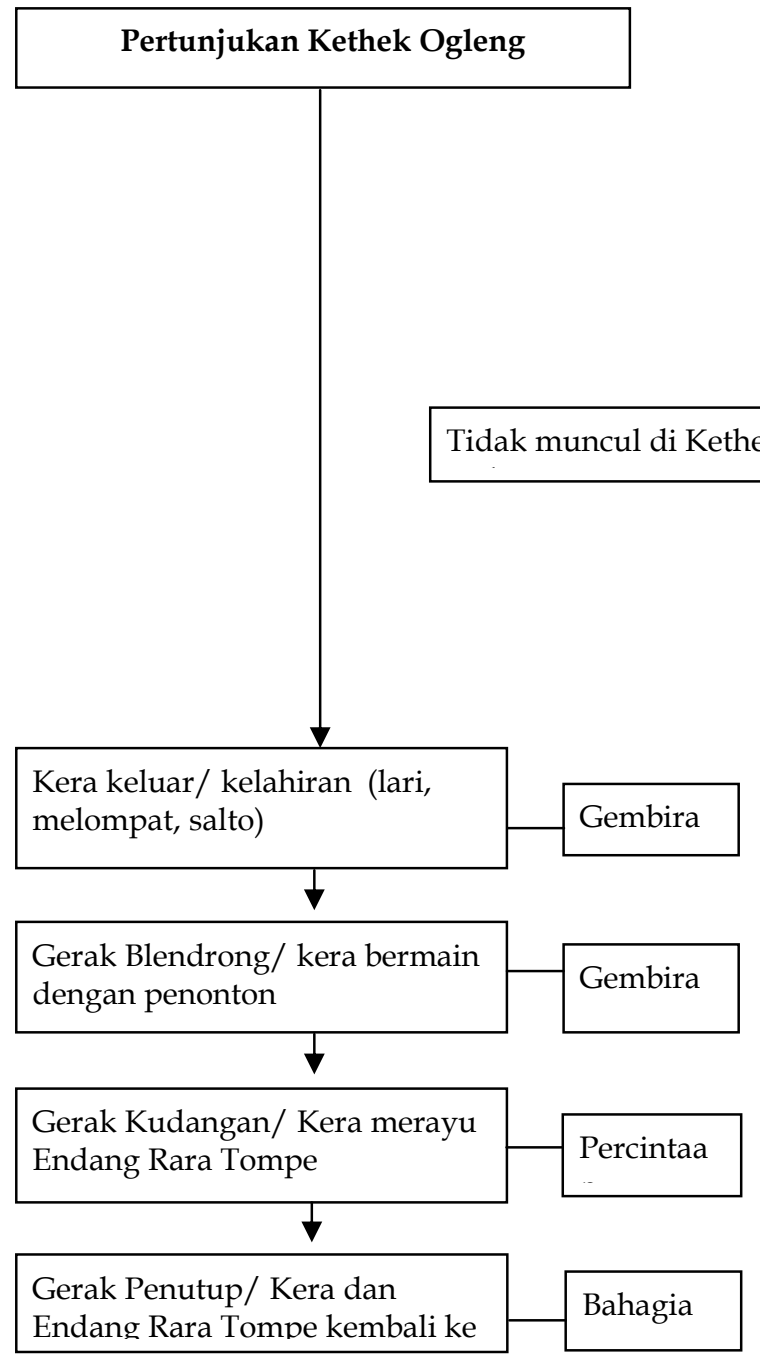

3.4 Pola Perpindahan dari Cerita (lisan) ke Pertunjukan (visual)

Dalam penelitian ini, perpindahan dari cerita Endang Rara Tompe ke pertunjukan Kethek Ogleng dilakukan dengan cara 1) pemotongan perisitiwa dan 2) perubahan fungsi tokoh. Hal itu akan diuraikan sebagai berikut:

\subsubsection{Pemotongan Adegan}

Cerita Endang Rara Tompe menceritakan petualangan dan percintaan Dewi sekartaji dengan Panji Asmarabangun. Kisah percintaan Endang Rara Tompe ini merupakan bagian dari kisah Panji yang banyak tersebar di nusantara.

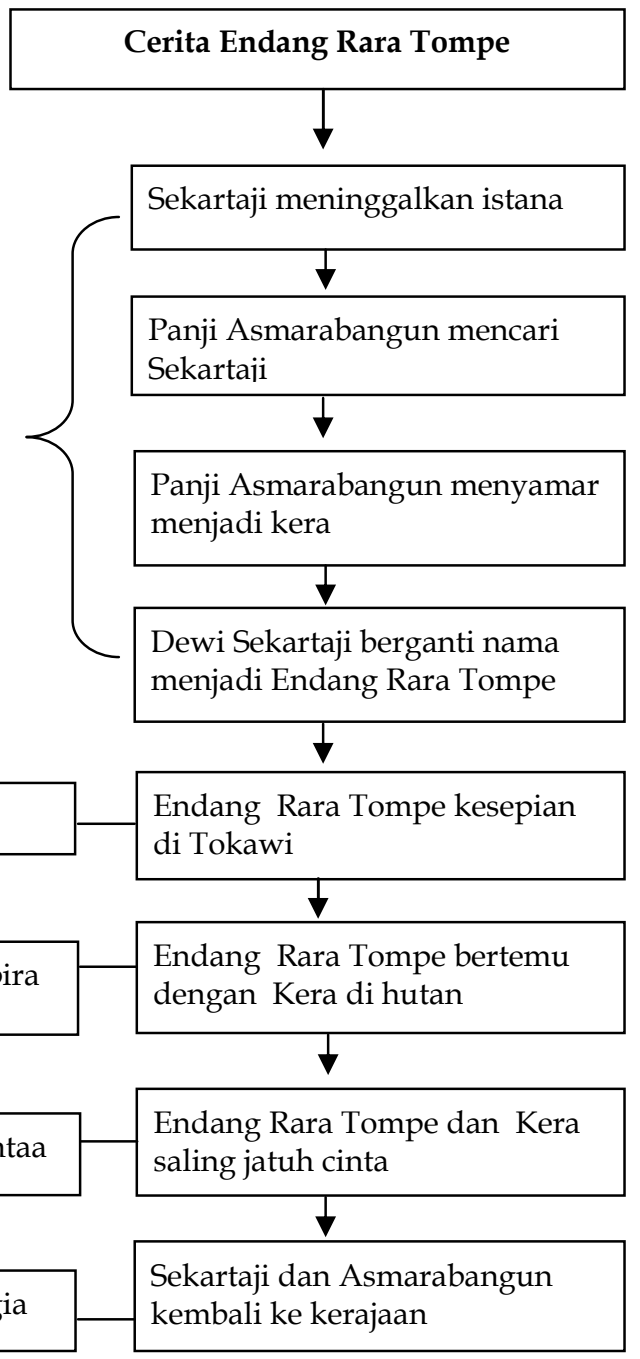

Cerita Endang Rara Tompe yang berkembang di Tokawi Nawangan mengisahkan petualangan Panji Asmarabangun mencari Dewi Sekartaji. Menurut cerita, Dewi Sekartaji pergi meninggalkan kerajaan karena dilararang menikah dengan Panji Asmarabangun.

Dalam perjalanan mencari Dewi Sekartaji, Panji Asmarabangun menyamar menjadi kera dan melakukan perjalanan ke arah barat. Sementara itu, dalam pelariannya, Dewi Sekartaji juga berjalan ke arah barat dan penyamar menjadi seorang gadis desa bernama Endang Rara Tompe. 
Endang Rara Tompe atau Dewi Sekartaji dan Kera atau Panji Asmorobangun diceritakan bertemu di Tokawi Nawangan. Keduanya bersahabat hingga akhirnya jatuh cinta. Akhir cerita, Dewi Sekartaji dan Panji Asmorobangun kembali ke kerajaan Jenggala untuk melangsungkan pernikahan.

Berdasar cerita tersebut, tidak semua bagian cerita muncul dalam adegan Kethek Ogleng. Terdapat beberapa peristiwa di cerita Endang Rara Tompe yang tidak muncul dalam pertunjukan Kethek Ogleng.

Adegan awal di kerajaan Jenggala, perjalanan Panji dan Sekartaji, dan proses penyamaran Sekartaji menjadi Endang Rara Tompe dan malih rupa Panji Asmarabangun menjadi kera tidak dimunculkan.

Pertunjukan Kethek Ogleng mengadegankan peristiwa kemunculan kera, pertemuan kera dengan Endang Rara Tompe, adegan jatuh cinta, dan adegan kembali ke kerajaan.

Adegan yang diceritakan dalam pertunjukan Kethek Ogleng divisualkan melalui gerak tari. Gerak tari Kethek Ogleng secara umum dibagi menjadi tiga jenis gerak yaitu: gerak improvisasi (gerak bebas beraturan), gerak pasti (Blendrongan), dan gerak kudangan.

Gerak improvisasi secara umum meniru gerakan kera di alam liar. Gerakan ini tidak memiliki patokan yang pasti. Namun, konsep utamanya yaitu meniru perilaku kera: cara berjalan, jongkok, melompat, berguling ke depan, berguling ke samping, bergelantungan, dan garuk kepala.

Gerakan meniru perilaku kera adalah hasil dari pengamatan Sutiman di pinggiran hutan Nawangan (wawancara dengan Sukisno, 8 Maret 2019).

Sementara itu, gerakan pakem yang ada di dalam pertunjukan Kethek Ogleng dipakai pada sesi Blendrongan dan Kudangan. Gerak Blendrongan dan Kudangan dilakukan secara serempak sesuai bunyi musik pengiring.

Dari sisi alur pertunjukan, Kethek Ogleng dibagi menjadi empat adegan, yaitu: adegan kethek muncul (adegan awal), blendrongan (kera bermain), kudangan (Kera digoda Endang Rara Tompe), dan adegan penutup (kembali ke Kerajaan) (Sutopo dkk., 2018).

Dalam kajian intertekstual, pengambilan beberapa peristiwa dari Hipogram untuk diubah menjadi karya yang baru banyak ditemukan. Secara teoritis, pemotongan peristiwa cerita Endang Rara Tompe untuk divisualkan menjadi pertunjukan Kethek Ogleng dinamakan konversi. Dalam peristiwa ini, Sutiman mengambil sebagian peritiwa dari cerita dan dikembangkan sesuai daya nalar yang dimiliki menjadi pertunjukan yang dapat dilihat.

\subsubsection{Perubahan Fungsi Tokoh}

Pergeseran posisi tokoh dalam kajian intertektual merupakan bagian dari konversi. Pengarang tidak hanya mengubah cerita tapi memutarbalikkan hipogram. Dalam pertunjukan Kethek Ogleng, Sutiman memodifikasi kemunculan tokoh. Baik secara kuantitas maupun kualitas. Sehingga secara teoretis terjadi perbuahan peran tokoh utama.

Pertunjukan Kethek Ogleng, tokoh utama berbeda dari hipogramnya. Terdapat pergeseran fungsi tokoh dalam pertunjukan Kethek Ogleng. Tokoh utama di cerita Endang Rara Tompe berbeda dengan tokoh utama dalam Kethek Ogleng.

Sesuai judulnya, Cerita Endang Rara Tompe ditokohutamai oleh Dewi Sekartaji atau Endang Rara Tompe. Sedangkan dalam tari Kethek Ogleng, tokoh kera menjadi tokoh utama.

Secara kuantitas maupun kualitas kemunculannya, tokoh utama cerita Endang Rara Tompe yaitu tokoh Dewi Sekartaji. Selain sebagai pembangun cerita, mulai awal cerita hingga akhir, tokoh Dewi Sekartaji selalu hadir. Baik langsung maupun tidak langsung atau hanya menjadi bahan pembicaraan tokoh lain. 
Sementara itu, tokoh utama pertunjukan Kethek Ogleng, yaitu seekor kera atau Panji Asmarabangun. Hal itu berdasar kemunculan dalam setiap adegan mulai awal pertunjukan hingga akhir. Sedangkan tokoh Endang Rara Tompe dalam pertunjukan Kethek Ogleng hanya muncul di tengah pertunjukan.

Secara kualitas, tokoh Endang Rara Tompe dalam pertunjukan Kethek Ogleng bukan yang utama. Berbeda dengan tokoh Dewi Sekartaji dalam cerita Endang Rara Tompe yang sebagai pembangun cerita,

Tokoh Endang Rara Tompe dalam Kethek Ogleng keberadannya hanya sebagai pelengkap dalam adegan Kudangan. Bahkan, akhir akhir ini keberadaan Endang Rara Tompe dalam adegan kudangan dapat digantikan dengan penonton atau orang lain di luar tim pertunjukan.

\section{Penutup}

Pertunjukan Kethek Ogleng yang diciptakan oleh Sutiman pada tahun 1962 merupakan hasil transformasi dari kisah Panji Endang Rara Tompe. Terdapat pola kesamaan antara struktur pertunjukan Kethek Ogleng dengan alur cerita kisah Panji Endang Rara Tompe.

Secara keseluruhan cerita Endang Rara Tompe hanya diambil beberapa pertistiwa saja. Peristiwa yang muncul di Kethek Ogleng yaitu kemunculan kera, pertemuan kera dengan Endang Rara Tompe, adegan jatuh cinta, dan adegan kembali ke kerajan.

Terdapat dua pola pemindahan dari hipogram cerita Endang Rara Tompe ke pertunjukan Kethek Ogleng. Pertama yaitu melalui pemotongan adegan. Dalam kasus ini, pencipta Kethek Ogleng hanya mengambil adegan pertemuan Endang Rara Tompe dengan kera, peristiwa Endang rara Tompe jatuh cinta kepada kera, dan kembalinya Endang Rara Tompe dan Kera ke kerajaan.

Pola pemindahan yang kedua yaitu alih tokoh utama. Bila di cerita Endang Rara Tompe tokoh utamanya adalah Dewi
Sekartaji, maka di Kethek Ogleng, tokoh utamanya yaitu seekor kera atau tokoh Panji Asmarabangun.

\section{Daftar Pustaka}

Andayani, A. 2011. "Transformasi Teks Dari Pancatantra India ke Tantri Kamandaka Jawa Kuno: Telaah Sastra Bandingan". Jurnal Ilmiah Kajian Sastra, Volume 14 No. 2. Hal 138-155., 14(2), 138-155.

Azizah, R. N., Bagiya, \& Faizah, U. 2018. "Kajian Intertekstualitas Novel Perempuan Berkalung Sorban Karya Abidah El Khalieqy dan Film Kartini Karya Hanung Bramantyo dan Rencana Pelaksanaan Pembelajarannya di Kelas XII SMA". 6(55), 676-683. gaya bahasa, novel, rencana pelaksanaan pembelajaran.

Haryatmo, S. 2015. "Kisah Nabi Khidir dalam Sastra Suluk: Resepsi dan Transformasi*)". 43(2), 177-188. https://doi.org/https:/ / doi.org/10.2649 9/wdprw.v43i2.116

Hasanah, F., Subekti, M., \& Tri Handayani, V. 2018. "Makna Realisme Magis dalam Novel Jours De Colère Dan 'Enfant Méduse Karya Sylvie Germain". Litera, 17(3), 316-335. https://doi.org/10.21831/ltr.v17i3.19990

Hikmah, F., \& Roihanah, R. 2017. "A Javanese Panji Romance: Analisis Struktur Cerita Panji Pada Naskah Wangbang Widaya". INTAJ: Jurnal Penelitian Ilmiah, 1(2), 2946.

https:/ / doi.org/10.35897/intaj.v1i2.93

Manuaba, I. B. 2013. "Keberadaan Dan Bentuk Transformasi Cerita Panji". Litera, 12(1). https://doi.org/10.21831/ltr.v12i01.1325 
Nurgiyantoro, B. 2005. Teori Pengkajian Fiksi. UGM Press.

Pigeaud, T. G. T. 1967. Literature of Java: Synopsis of Javanese literature 900-1900 A.D. Springer.

Poerbatjaraka, R. M. N. 1968. Tjerita Pandji dalam Perbandingan. Gunung Agung.

Ramadhanti, D., \& Yanda, D. P. 2018. "Transformasi Teks Kaba Sabai Nan Aluih Menjadi Komik Kaba Sabai Nan Aluih". Atavisme, 21(2), 194-208.

Ratna, N. K. 2010. Sastra Dan Cultural Studies: Representasi Fiksi Dan Fakta. In Pustaka Pelajar.

Ratna, N. K. 2020. Sastra dan Cultural Studies: Representasi Fiksi dan Fakta. Pustaka Pelajar.

Riffaterre, M. 1978. Semiotic Of Poetry. Indiana Of University Perss.
Rohidi, T. R. 2011. Metodologi Penelitian Seni. Citra Prima Nusantara.

Santosa, P., \& Djamari. 2013. "Kajian Intertekstual Tiga Puisi tentang Nabi Luth Bersama Kaum Sodom dan Gomora". Widyaparwa, 41(1), 13--28.

Sidik, U. 2016. "Tranformasi Kisah Ashabul Kahfi Dalam Ahlul Kahfi Karya Taufiq Al-Hakim (Transformation Story "Ashabul Kahfi" in Ahlul Kahfi By Taufiq Al-Hakim)". Widyaparwa, 44(2), 122-135.

https://doi.org/10.26499/wdprw.v44i2.144

Suseno, C. A. 2013. Nilai-Nilai Sosial Kesenian Kethek Ogleng di Desa Tokawi Kecamatan Nawangan Kabupaten Pacitan, Jawa Timur.

Sutopo, B., Hendriyanto, A., \& Mustofa, A. (2018. Kethek Ogleng Kesenian Monumental Asli Tanah Pacitan. Ladang Kata. 